\title{
KOMPONEN UTAMA \\ UNTUK PENGENDALIAN KUALITAS SECARA STATISTIK
}

\author{
Nunik Nurhasanah ${ }^{1}$, Diah Safitri ${ }^{2}$ \\ ${ }^{1}$ Alumni Program Studi Statistika FMIPA UNDIP \\ ${ }^{2}$ Staf Pengajar Program Studi Statistika FMIPA UNDIP
}

\begin{abstract}
Statistically Quality Control is a problem solving technique that used to check, control, analyze, bring off and repair product with statistical methods. One of the method that used statistically control quality is Principal Component Analysis. Principal Component Analysis is a multivariate technique that used to reduce the dimension of data. Principal component is concerned with explaining the variance-covariance structure of a set of variables through a few linear combinations of these variables. Statistically quality control with principal components is used by constructing multivariate control charts which consist of Ellipse Chart for first two principal components and $T^{2}$ Chart for unexplained principal components in Ellipse Chart.
\end{abstract}

Keywords : Principal Component Analysis, Ellipse Chart, $T^{2}$ Chart

\section{Pendahuluan}

Untuk meningkatkan kualitas produk dan pelayanan perlu dilakukan pemeriksaan data untuk mengetahui penyebab adanya variasi. Pengendalian kualitas secara statistik dilakukan dengan menggunakan grafik pengendali. Tujuan pengendalian kualitas adalah menyidik dengan cepat terjadinya sebab-sebab terduga atau pergeseran proses sedemikian hingga penyelidikan terhadap proses tersebut dan tindakan pembetulan dapat dilakukan sebelum terlalu banyak unit yang tak sesuai diproduksi ${ }^{[2]}$. Grafik pengendali memisahkan penyebab penyimpangan menjadi penyebab umum dan penyebab khusus melalui batas pengendalian. Bila penyimpangan atau kesalahan melebihi batas pengendalian menunjukkan bahwa penyebab khusus telah masuk ke dalam proses dan proses harus diperiksa untuk mengidentifikasi penyebab dari penyimpangan atau kesalahan yang berlebihan tersebut. Kesalahan yang disebabkan oleh penyebab umum berada di dalam batas pengendalian. Dalam proses sebaiknya hanya terjadi kesalahan yang disebabkan oleh penyebab umum sehingga secara langsung kesalahan tersebut dapat distabilkan.

Grafik pengendali multivariat adalah grafik pengendali untuk pengamatan multivariat, diantaranya grafik berbentuk elips dan grafik $T^{2}$. Grafik berbentuk elips digunakan untuk daerah pengendalian bivariat, yaitu identifikasi yang terbatas pada dua variabel, sedangkan grafik $\mathrm{T}^{2}$ untuk jumlah karakteristik yang lebih besar.

Pada pengamatan multivariat dengan jumlah variabel yang terlalu banyak, digunakan komponen utama untuk pengendalian kualitas secara statistik. Analisis komponen utama (Principal Component Analysis) merupakan prosedur statistis untuk mendapatkan komponen utama yang mampu mempertahankan sebagian informasi yang terkandung pada data asal ${ }^{[3]}$. Tujuan utama dari analisis komponen utama adalah mereduksi data ${ }^{[4]}$. Pada tulisan ini akan dibahas bagaimana cara menggunakan komponen utama untuk pengendalian kualitas secara statistik. Langkah-langkah yang dilakukan adalah memeriksa stabilitas sekumpulan komponen utama yang diberikan dengan menggunakan grafik pengendali, apabila terdapat pengukuran yang berada di luar batas- 
batas pengendali maka dilanjutkan ke tahap berikutnya, yaitu memperbaiki proses agar proses dalam kondisi stabil (semua pengukuran berada dalam batas-batas pengendali).

\section{Kajian Teori}

\subsection{Analisis Komponen Utama}

Analisis komponen utama merupakan salah satu teknik statistika multivariat yang dapat digunakan untuk menyederhanakan suatu data, dengan cara melakukan transformasi linear sehingga terbentuk sistem koordinat baru dengan varian maksimum. Misalkan terdapat $\mathrm{p}$ komponen utama dengan $\mathrm{n}$ observasi. Meskipun $\mathrm{p}$ komponen dibutuhkan untuk menerangkan variabilitas sistem secara total, seringkali variabilitas ini dapat diterangkan oleh $k(k<p)$ komponen utama. Dalam hal ini baik $p$ komponen maupun k komponen utama memberikan (hampir) sejumlah informasi yang sama. Hal ini dikarenakan $k$ komponen utama dapat menggantikan $p$ variabel asal dan data yang semula terdiri dari $n$ pengukuran pada $p$ variabel menjadi $n$ pengukuran pada $k$ komponen utama ${ }^{[4]}$.

\subsection{Grafik Pengendali Multivariat}

Grafik pengendali multivariat diantaranya adalah grafik berbentuk elips dan grafik $T^{2}$. Grafik berbentuk elips digunakan untuk daerah pengendalian bivariat, yaitu identifikasi yang terbatas pada dua variabel. Dua variabel dalam unit ke-j digambarkan sebagai suatu pasangan $\left(x_{j 1}, x_{j 2}\right)$. Elips kualitas 95\% terdiri dari semua $x$ yang memenuhi

$$
(\underset{\sim}{x}-\bar{x})^{T} S^{-1}(\underset{\sim}{x}-\bar{x}) \leq \chi_{2}^{2}(0.05)
$$

Grafik $T^{2}$ bisa digunakan untuk variabel dengan jumlah besar, tidak seperti grafik pengendali berbentuk elips yang hanya terbatas pada dua variabel. Lebih dari itu, titik-titik yang terdapat dalam urutan waktu pada grafik $T^{2}$ lebih baik dari diagram pencar dan grafik ini memungkinkan terbentuknya pola dan kecenderungan (trend). Untuk titik ke-j digunakan statistik $T^{2}, \mathrm{~T}_{\mathrm{j}}^{2}=\left(\mathrm{x}_{\mathrm{j}}-\underset{\sim}{\overline{\mathrm{x}}}\right)^{\mathrm{T}} \mathrm{S}^{-\mathrm{i}}\left(\mathrm{x}_{\mathrm{j}}-\underset{\sim}{\overline{\mathrm{x}}}\right)$. Kemudian nilai-nilai $T^{2}$ diletakkan pada sumbu-y dan waktu/observasi pada sumbu-x. Batas Pengendali Bawah (BPB) adalah 0 dan Batas Pengendali Atas $(\mathrm{BPA})=\chi_{p}^{2}(\alpha)$ dengan $\alpha=0,05$ atau $0,01^{[1]}$.

\section{Pengkonstruksian Grafik Pengendali}

Diberikan $\sum$ matriks varian-kovarian yang berasosiasi dengan vektor random ${\underset{\sim}{x}}^{T}=\left[x_{1}, x_{2}, \ldots, x_{p}\right] . \Sigma$ memiliki pasangan nilai eigen - vektor eigen

$$
\left(\lambda_{1}, e_{\sim}\right),\left(\lambda_{2}, e_{\sim}\right), \ldots,\left(\lambda_{p},{\underset{\sim}{p}}_{\sim}\right) \text { dengan } \lambda_{1} \geq \lambda_{2} \geq \cdots \geq \lambda_{p} \geq 0 .
$$

Komponen utama ke- $i$ adalah:

$$
y_{i}=e_{\sim}^{T} \underset{\sim}{x}=e_{i 1} x_{1}+e_{i 2} x_{2}+\cdots+e_{i p} x_{p} \quad, i=1,2, \ldots, p
$$

dengan:

$$
\begin{array}{ll}
\operatorname{var}\left(y_{i}\right)=e_{\sim}^{T} \sum e_{\sim}=\lambda_{i} & , i=1,2, \ldots, p \\
\operatorname{cov}\left(y_{i}, y_{k}\right)=e_{i}^{T} \sum e_{k}=0 & , i \neq k
\end{array}
$$


Jika $\mathrm{S}=\left\{\mathrm{s}_{\mathrm{ik}}\right\}$ adalah matriks varian-kovarian sampel $p \times p$ dengan pasangan nilai eigen-vektor eigen $\left(\hat{\lambda}_{1}, \hat{e}_{\sim}\right),\left(\hat{\lambda}_{2}, \hat{e}_{\sim}\right), \ldots,\left(\hat{\lambda}_{p}, \hat{e}_{p}\right)$, komponen utama ke-i diberikan dengan:

$$
\hat{y}_{i}=\hat{e}_{i}^{T} \underset{\sim}{x}=\hat{e}_{i 1} x_{1}+\hat{e}_{i 2} x_{2}+\cdots+\hat{e}_{i p} x_{p}, i=1,2, \ldots, p
$$

dimana $\hat{\lambda}_{1} \geq \hat{\lambda}_{2} \geq \cdots \geq \hat{\lambda}_{p} \geq 0$ dan $\underset{\sim}{x}$ adalah observasi pada variabel $\mathrm{x}_{1}, \mathrm{x}_{2}, \ldots, \mathrm{x}_{\mathrm{p}}$.

Varian sampel $\left(\hat{y}_{k}\right)=\hat{\lambda}_{k} \quad, k=1,2, \ldots, p$ dan kovarian sampel $\left(\hat{y}_{i}, \hat{y}_{k}\right)=0 \quad, i \neq k$. Total varian sampel $=\sum_{i=1}^{p} s_{i i}=\hat{\lambda}_{1}+\hat{\lambda}_{2}+\cdots+\hat{\lambda}_{p}$

Hasil dari komponen utama yang diperoleh dapat disajikan dalam bentuk grafik. Grafik komponen utama dapat memperkirakan observasi sebaik pengecekan asumsi normal. Komponen utama merupakan kombinasi linear dari variabel awal, sehingga beralasan untuk menduganya mendekati normal. Grafik ini perlu untuk memeriksa bahwa beberapa komponen utama pertama berdistribusi normal ketika komponen utamakomponen utama tersebut digunakan sebagai data input untuk analisis tambahan.

Komponen utama-komponen utama terakhir bisa membantu menunjukkan dengan tepat perkiraan observasi. Setiap observasi dapat ditunjukkan sebagai suatu kombinasi linear:

$$
\begin{aligned}
x_{j} & =\left(\underset{\sim}{x_{j}^{T}} \hat{e}_{1}\right) \hat{e}_{1}+(\underbrace{T}_{\sim} \hat{e}_{2}) \hat{e}_{2}+\cdots+\left(\sim_{\sim}^{T} \hat{e}_{p}\right) \hat{e}_{p} \\
& =\hat{y}_{j 1} \hat{e}_{\sim}+\hat{y}_{j 2} \hat{e}_{2}+\cdots+\hat{y}_{j p} \hat{e}_{p}
\end{aligned}
$$

dari himpunan lengkap vektor eigen $\hat{e}_{1}, \hat{e}_{2}, \ldots, \hat{e}_{p}$ matriks varian-kovarian S. Karena itu, besarnya komponen utama-komponen utama terakhir menunjukkan seberapa baik kecocokan beberapa komponen utama yang pertama. Ini berarti $\hat{y}_{j 1} \hat{e}_{1}+\hat{y}_{j 2} \hat{e}_{2}+\cdots+\hat{y}_{j . q-1} \hat{e}_{q-1}$ berbeda dari $x_{j}$ oleh $\hat{y}_{j q} \hat{e}_{q}+\cdots+\hat{y}_{j p} \hat{e}_{p}$.

\subsection{Pemeriksaan Stabilitas Komponen Utama}

Pemeriksaan stabilitas komponen utama dilakukan dengan prosedur dua-bagian, yaitu:

\section{a. Prosedur Bagian Pertama}

Diberikan dua komponen utama sampel yang pertama, yaitu $\hat{y}_{j 1}=\hat{e}_{1}^{T}\left(x_{j}-\bar{x}\right)$ dan $\hat{y}_{j 2}=\hat{e}_{2}^{T}\left(x_{j}-\underset{\sim}{\bar{x}}\right)$. Dua komponen pertama dipilih karena kedua komponen tersebut menjelaskan proporsi kumulatif terbesar dari total varian sampel.

Jika proses stabil sepanjang waktu, karakteristik yang diukur hanya dipengaruhi oleh variasi yang ditimbulkan penyebab umum, maka nilai-nilai dari dua komponen pertama menjadi stabil. Bagian pertama dari prosedur ini adalah membuat grafik berbentuk elips untuk pasangan nilai-nilai $\left(\hat{y}_{j 1}, \hat{y}_{j 2}\right)$ dimana $j=1,2, \ldots, n$.

Varian sampel dari komponen utama pertama $\hat{y}_{1}$ diberikan dengan nilai eigen terbesar $\hat{\lambda}_{1}$ dan varian sampel dari komponen utama kedua $\hat{y}_{2}$ adalah nilai eigen terbesar kedua $\hat{\lambda}_{2}$. Dua komponen utama sampel tidak berkorelasi. Elips kualitas untuk $n$ besar mungkin akan mengurangi koleksi pasangan dari nilai $\left(\hat{y}_{1}, \hat{y}_{2}\right)$ supaya 


$$
\frac{\hat{y}_{1}^{2}}{\hat{\lambda}_{1}}+\frac{\hat{y}_{2}^{2}}{\hat{\lambda}_{2}} \leq \chi_{2}^{2}(\alpha)
$$

Apabila terdapat pasangan nilai-nilai $\left(\hat{y}_{j 1}, \hat{y}_{j 2}\right)$ yang tidak memenuhi pertidaksamaan elips (4), yaitu berada di luar elips berarti proses dalam keadaan tidak stabil. Penyebab khusus mungkin telah masuk ke dalam proses dan proses harus diperiksa untuk mengidentifikasi penyebab dari penyimpangan atau kesalahan tersebut.

\section{b. Prosedur Bagian Kedua}

Ketika proses pada grafik elips tidak stabil, diperlukan grafik $T^{2}$. Grafik ini memuat informasi dari komponen utama yang tidak digunakan dalam grafik berbentuk elips.

Diberikan vektor deviasi $\underset{\sim}{x-} \mu$, dan dianggap bahwa $\underset{\sim}{x}$ berdistribusi $\mathrm{N}_{\mathrm{p}}\left(\mu, \sum\right)$, dengan

$$
\begin{aligned}
& \underset{\sim}{x-\mu}=(\underset{\sim}{\mu}-\underset{\sim}{\mu}) e_{1}{ }^{T} e_{1}+(\underset{\sim}{x-\mu}) e_{\sim}{ }^{T} e_{\sim}+(\underset{\sim}{x}-\underset{\sim}{\mu}) e_{3}{ }^{T} e_{\sim}+\cdots+(\underset{\sim}{x}-\underset{\sim}{\mu}) e_{p}{ }^{T} e_{p} \\
& \text { atau } \\
& \underset{\sim}{x-\mu}=y_{1} e_{1}+y_{2} e_{2}+y_{3} e_{3}+\cdots+y_{p} e_{p}
\end{aligned}
$$

dengan $\left.y_{i}=\underset{\sim}{x}-\mu\right) e_{i}{ }^{T}$ adalah komponen utama populasi ke- $i$ yang memiliki rata-rata 0 . Perkiraan $\underset{\sim}{x-\mu}$ oleh dua komponen utama pertama memiliki bentuk $y_{1} e_{1}+y_{2} e_{2}$. Perkiraan ini menyisakan komponen utama yang tak dijelaskan $\underset{\sim}{x-}-\mu-y_{1} e_{1}-y_{2} e_{2}$.

Diberikan $E=\left[\underset{\sim}{e_{1}, e_{2}, \ldots, e_{p}}\right]$ adalah matriks ortogonal yang kolom-kolomnya adalah vektor eigen dari $\sum$. Transformasi ortogonal dari bagian tak dijelaskan,

$$
\left.E_{\sim}^{T} \underset{\sim}{\left(x-y_{1}\right.} \underset{\sim}{e_{1}-y_{2}}{\underset{\sim}{2}}_{\sim}\right)=\left[\begin{array}{c}
y_{1} \\
y_{2} \\
y_{3} \\
\vdots \\
y_{p}
\end{array}\right]-\left[\begin{array}{c}
y_{1} \\
0 \\
0 \\
\vdots \\
0
\end{array}\right]-\left[\begin{array}{c}
0 \\
y_{2} \\
0 \\
\vdots \\
0
\end{array}\right]=\left[\begin{array}{c}
0 \\
0 \\
y_{3} \\
\vdots \\
y_{p}
\end{array}\right]=\left[\begin{array}{c}
0 \\
0 \\
y_{(2)}
\end{array}\right]
$$

Jadi ( $p$-2) komponen utama terakhir diperoleh sebagai suatu transformasi ortogonal dari pendugaan error. Dasar dari grafik $T^{2}$ diperoleh dari pendugaan error yaitu dari komponen utama-komponen utama terakhir. Diketahui bahwa $\operatorname{var}\left(\mathrm{y}_{\mathrm{i}}\right)=\lambda_{\mathrm{i}}$ untuk $\mathrm{i}=1,2, \ldots, \mathrm{p}$ dan $\operatorname{cov}\left(\mathrm{y}_{\mathrm{i}}, \mathrm{y}_{\mathrm{k}}\right)=0 \quad$ untuki $\neq \mathrm{k}$. Akibatnya statistik $y_{(2)}^{T} \sum_{y_{(2)} \cdot y_{(2)}}^{-1} y_{(2)}$ berdasarkan pada $(p-2)$ komponen utama populasi terakhir, menjadi

$$
\frac{y_{3}^{2}}{\lambda_{3}}+\frac{y_{4}^{2}}{\lambda_{4}}+\cdots+\frac{y_{p}^{2}}{\lambda_{p}}
$$

ini hanya jumlah kuadrat dari $(p-2)$ variabel normal standar independen $\lambda_{k}^{-1 / 2} y_{k}$, dan juga memiliki distribusi chi-square dengan derajat bebas $(p-2)$. 
Dalam hubungannya dengan data sampel, komponen utama dan nilai eigen harus diestimasi. Koefisien dari kombinasi linear $\hat{e}_{i}$ juga mengestimasi komponen utama yang tidak berdistribusi normal bahkan ketika populasinya normal. Bagaimanapun hal ini biasa dilakukan untuk membuat grafik $T^{2}$ berdasarkan statistik

$$
T_{j}^{2}=\frac{\hat{y}_{j 3}^{2}}{\hat{\lambda}_{3}}+\frac{\hat{y}_{j 4}^{2}}{\hat{\lambda}_{4}}+\cdots+\frac{\hat{y}_{j p}^{2}}{\hat{\lambda}_{p}}
$$

yang melibatkan estimasi nilai eigen dan vektor eigen. Batas pengendali atas dari grafik $T^{2}$ adalah $B P A=c^{2}=\chi_{p-2}^{2}(\alpha)$.

Statistik $T^{2}$ ini dapat digunakan pada data berdimensi tinggi. Sebagai contoh, ketika $p=20$ variabel diukur, $T^{2}$ menggunakan informasi yang berasal dari $p-2=20-2$ $=18$ dimensi yang tegak lurus pada dua vektor eigen pertama $\hat{e}_{i}$ dan $\hat{e}_{2}$.

\subsection{Pengendalian Nilai yang Akan Datang}

Setelah dilakukan pemeriksaan stabilitas yang dilakukan secara terpisah pada dua komponen utama pertama dan ( $p$-2) komponen utama terakhir, akan dilakukan perbaikan agar proses stabil sepanjang waktu. Karena distribusi chi-square digunakan untuk menduga BPA grafik $T^{2}$ dan jarak kritis untuk grafik bentuk elips, modifikasi tidak lagi perlu untuk pengendalian nilai yang akan datang.

Contoh penggunaan pengendalian kualitas secara statistik pada data multivariabel dapat dijumpai di bidang industri kimia dan farmasi, lebih dari 100 variabel dikendalikan secara bersama-sama. Proses ini termasuk proses yang melibatkan variabel dalam jumlah yang sangat besar. Dengan demikian terdapat lebih dari 100 komponen utama sehingga terdapat nilai eigen yang sangat kecil. Pendekatan alternatif dibutuhkan dalam pembuatan grafik pengendali untuk menghindari kesulitan yang disebabkan oleh pembagian kuadrat komponen utama yang sangat kecil akibat dari nilai eigen yang sangat kecil.

Untuk setiap observasi stabil, ditetapkan jumlah kuadrat dari komponen utama yang tidak digunakan dalam grafik elips adalah:

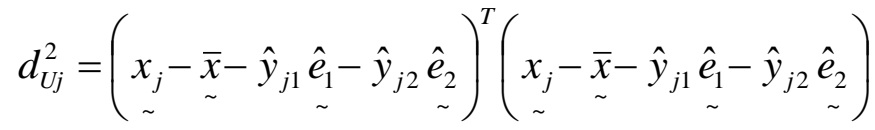

dengan memasukkan $\hat{E} \hat{E}^{T}=I$ pada (7), diperoleh

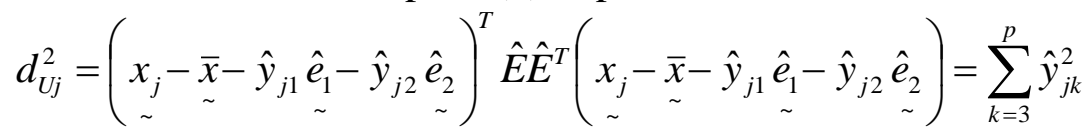

yang juga merupakan jumlah kuadrat dari $(p-2)$ komponen utama terakhir.

Penggunaan $d_{U j}^{2}$ pada grafik pengendali akan digambarkan $d_{U j}^{2}$ versus $j$. Batas Pengendali Bawah (BPA) dari grafik adalah 0 dan Batas Pengendali Atas (BPA) diatur dengan pendugaan distribusi $d_{U j}^{2}$ seperti distribusi dari konstanta $c$ pada saat variabel random chi-square memiliki derajat bebas $v$.

Untuk pendugaan chi-square, konstanta $c$ dan derajat bebas $v$ dipilih untuk menyesuaikan rata-rata dan varian sampel dari $d_{U j}^{2}, j=1,2, \ldots, n$. Secara khusus

$$
\bar{d}_{U}^{2}=\frac{1}{n} \sum_{j=1}^{n} d_{U j}^{2}=c v
$$




$$
s^{2} d^{2}=\frac{1}{n-1} \sum_{j=1}^{n}\left(d_{U j}^{2}-\bar{d}_{U}^{2}\right)^{2}=2 c^{2} v
$$

dan menentukan $c=\frac{s^{2} d^{2}}{2 d_{U}^{2}}, \quad v=2 \frac{\left(\bar{d}_{U}^{2}\right)^{2}}{s^{2} d^{2}}$.

Batas Pengendali Atas (BPA) adalah $c \chi_{v}^{2}(\alpha)$ dimana $\alpha=0,05$ atau 0,01 .

\subsection{Contoh Penerapan}

Dalam tulisan ini digunakan data catatan waktu berbagai nomor lari putra cabang atletik yang diikuti oleh 55 negara, Data diambil dari Johnson, R.A. dan Wichern, D.W., 2007. Variabel yang digunakan adalah $x_{1}=$ Catatan waktu atlet lari 100 meter (dalam detik $), x_{2}=$ Catatan waktu atlet lari 200 meter ( dalam detik ), $x_{3}=$ Catatan waktu atlet lari 400 meter ( dalam detik ), $x_{4}=$ Catatan waktu atlet lari 800 meter ( dalam menit ), $x_{5}=$ Catatan waktu atlet lari 1500 meter ( dalam menit ), $x_{6}=$ Catatan waktu atlet lari 5000 meter ( dalam menit ), $x_{7}=$ Catatan waktu atlet lari 10000 meter ( dalam menit ), $x_{8}=$ Catatan waktu atlet maraton $=42195$ meter ( dalam menit ). Pada data tersebut satuan pengukuran berbeda (menit dan detik), sehingga dilakukan konversi satuan ke dalam satuan kecepatan meter/detik karena akan digunakan matriks varian-kovarian dalam pembentukan komponen utama yang memerlukan satuan pengukuran yang sama pada tiap variabel. Selanjutnya dilakukan penghitungan nilai eigen dari matriks varian-kovarian. Dari 8 buah nilai eigen diperoleh 8 buah vektor eigen yang bersesuaian dengan nilai eigen masing-masing.

Diperoleh matriks varian-kovarian sebagai berikut $\operatorname{Var}\left(x_{1}\right)=0.0899, \operatorname{var}\left(x_{2}\right)=$ 0.0829, $\operatorname{var}\left(x_{3}\right)=0.0668, \operatorname{var}\left(x_{4}\right)=0.0629, \operatorname{var}\left(x_{5}\right)=0.0717, \operatorname{var}\left(x_{6}\right)=0.1042, \operatorname{var}\left(x_{7}\right)=$ $0.1095, \operatorname{var}\left(x_{8}\right)=0.1019$. Varian yang terbesar diberikan oleh variabel $x_{7}$ dan varian terkecil diberikan oleh variabel $x_{4}$.

$$
\operatorname{Cov}\left(x_{1}, x_{2}\right)=\operatorname{cov}\left(x_{2}, x_{1}\right)=0.0797, \operatorname{cov}\left(x_{2}, x_{3}\right)=\operatorname{cov}\left(x_{3}, x_{2}\right)=0.0631, \operatorname{cov}\left(x_{3}, x_{4}\right)=
$$

$\operatorname{cov}\left(x_{4}, x_{3}\right)=0.0565, \operatorname{cov}\left(x_{4}, x_{5}\right)=\operatorname{cov}\left(x_{5}, x_{4}\right)=0.0609, \operatorname{cov}\left(x_{5}, x_{6}\right)=\operatorname{cov}\left(x_{6}, x_{5}\right)=$ 0.0799. Seluruh nilai $\operatorname{cov}\left(x_{i}, x_{j}\right)$ dengan $i=j=1,2, \ldots, 8$ dapat dilihat pada matriks variankovarian berikut ini:

$$
S=\left[\begin{array}{llllllll}
0.0899 & 0.0797 & 0.0642 & 0.0566 & 0.0555 & 0.0580 & 0.0606 & 0.0483 \\
0.0797 & 0.0829 & 0.0631 & 0.0580 & 0.0595 & 0.0637 & 0.0653 & 0.0540 \\
0.0642 & 0.0631 & 0.0668 & 0.0565 & 0.0576 & 0.0641 & 0.0666 & 0.0580 \\
0.0566 & 0.0580 & 0.0565 & 0.0629 & 0.0609 & 0.0690 & 0.0710 & 0.0637 \\
0.0555 & 0.0595 & 0.0576 & 0.0609 & 0.0717 & 0.0799 & 0.0824 & 0.0736 \\
0.0580 & 0.0637 & 0.0641 & 0.0690 & 0.0799 & 0.1042 & 0.1038 & 0.0956 \\
0.0606 & 0.0653 & 0.0666 & 0.0710 & 0.0824 & 0.1038 & 0.1095 & 0.0995 \\
0.0483 & 0.0540 & 0.0580 & 0.0637 & 0.0736 & 0.0956 & 0.0995 & 0.1019
\end{array}\right]
$$


Nilai eigen dari matriks varian-kovarian yang diperoleh diurutkan dari yang terbesar hingga yang terkecil. Nilai eigen dan vektor eigen yang bersesuaian terlihat pada Tabel 1.

Tabel 1. Nilai Eigen dan Vektor Eigen

\begin{tabular}{|ccccccccc|}
\hline Var & $\hat{e}_{1}$ & $\hat{e}_{2}$ & $\hat{e}_{3}$ & $\hat{e}_{4}$ & $\underset{\hat{e}_{5}}{\sim}$ & $\hat{e}_{6}$ & $\hat{e}_{7}$ & $\hat{e}_{8}$ \\
& $\sim$ & $\sim$ & $\sim$ & $\sim$ & $\sim$ \\
\hline & 0.3149 & 0.5992 & -0.3433 & 0.1795 & 0.0555 & -0.5991 & 0.1178 & 0.1258 \\
\hline$x_{1}$ & 0.3249 & 0.4722 & -0.2978 & -0.2329 & 0.0821 & 0.6970 & -0.1369 & -0.1315 \\
\hline$x_{3}$ & 0.3090 & 0.2325 & 0.5851 & 0.5240 & -0.4457 & 0.1840 & 0.0104 & 0.0313 \\
\hline$x_{4}$ & 0.3123 & 0.0592 & 0.5436 & -0.2109 & 0.6185 & -0.1890 & -0.3557 & -0.1193 \\
\hline$x_{5}$ & 0.3416 & -0.0782 & 0.2180 & -0.4916 & -0.0555 & 0.0163 & 0.7281 & 0.2336 \\
\hline$x_{6}$ & 0.4064 & -0.2952 & -0.1488 & -0.2339 & -0.3586 & -0.0960 & -0.5240 & 0.5084 \\
\hline$x_{7}$ & 0.4193 & -0.2994 & -0.1558 & -0.0493 & -0.2600 & -0.1883 & 0.0182 & -0.7775 \\
\hline$x_{8}$ & 0.3802 & -0.4214 & -0.2482 & 0.5438 & 0.4581 & 0.2019 & 0.1890 & 0.1849 \\
\hline$\hat{\lambda}_{i}$ & 0.5654 & 0.0832 & 0.0124 & 0.0093 & 0.0068 & 0.0059 & 0.0042 & 0.0027 \\
\hline
\end{tabular}

Kontribusi tiap komponen utama dihitung dengan rumus:

$$
\frac{\lambda_{i}}{\sum_{i=1}^{8} \lambda_{i}} \times 100 \%
$$

Diperoleh $\sum_{i=1}^{8} \lambda_{i}=0.5654+0.0832+0.0121+0.0093+0.0068+0.0059+0.0042+$ $0.0027=0.6899$. Kontribusi tiap komponen utama $(\mathrm{KU})$ adalah:

- $\mathrm{KU}_{1}=\frac{\lambda_{1}}{\sum_{i=1}^{8} \lambda_{i}} x 100 \%=\frac{0.5654}{0.6899} \times 100 \%=81.97 \%$

- $\mathrm{KU}_{2}=\frac{\lambda_{2}}{\sum_{i=1}^{8} \lambda_{i}} \times 100 \%=\frac{0.0832}{0.6899} \times 100 \%=12.06 \%$

- $\mathrm{KU}_{3}=\frac{\lambda_{3}}{\sum_{i=1}^{8} \lambda_{i}} \times 100 \%=\frac{0.0121}{0.6899} \times 100 \%=1.79 \%$

- $\mathrm{KU}_{4}=\frac{\lambda_{4}}{\sum_{i=1}^{8} \lambda_{i}} \times 100 \%=\frac{0.0093}{0.6899} \times 100 \%=1.35 \%$

- $\mathrm{KU}_{5}=\frac{\lambda_{5}}{\sum_{i=1}^{8} \lambda_{i}} \times 100 \%=\frac{0.0068}{0.6899} \times 100 \%=0.99 \%$ 


$$
\begin{aligned}
& \bullet \mathrm{KU}_{6}=\frac{\lambda_{6}}{\sum_{i=1}^{8} \lambda_{i}} \times 100 \%=\frac{0.0059}{0.6899} \times 100 \%=0.86 \% \\
& -\mathrm{KU}_{7}=\frac{\lambda_{7}}{\sum_{i=1}^{8} \lambda_{i}} \times 100 \%=\frac{0.0042}{0.6899} \times 100 \%=0.61 \% \\
& \bullet \mathrm{KU}_{8}=\frac{\lambda_{8}}{\sum_{i=1}^{8} \lambda_{i}} \times 100 \%=\frac{0.0027}{0.6899} \times 100 \%=0.39 \%
\end{aligned}
$$

Dari hasil perhitungan kontribusi masing-masing komponen utama dapat dilihat bahwa 2 komponen utama pertama mampu menerangkan $81.97 \%+12.06 \%=94.03 \%$ dari varian total. Dua komponen utama pertama sudah dapat menjelaskan $94.03 \%$ keragaman, maka untuk selanjutnya kedua komponen utama ini sudah layak digunakan sebagai variabel baru dalam pembentukan grafik pengendali berbentuk elips. Dua komponen utama sampel yang pertama, yaitu

$$
\begin{aligned}
\hat{y}_{1}= & 0.3149\left(x_{1}-9.5600\right)+0.3249\left(x_{2}-9.5600\right)+0.3090\left(x_{3}-8.6218\right)+ \\
& 0.3123\left(x_{4}-7.4453\right)+0.3416\left(x_{5}-6.7709\right)+0.4064\left(x_{6}-6.0375\right)+ \\
& 0.4193\left(x_{7}-5.7695\right)+0.3802\left(x_{8}-5.1686\right)
\end{aligned}
$$

Setelah diperoleh komponen utama, langkah selanjutnya adalah melakukan pemeriksaan stabilitas komponen utama. Tahapan yang dilakukan adalah membuat grafik pengendali elips untuk dua komponen utama pertama dan grafik $T^{2}$ untuk enam komponen utama yang tersisa.

Dari dua komponen utama pertama diperoleh batas pengendali elips:

$$
\frac{\hat{y}_{1}^{2}}{\hat{\lambda}_{1}}+\frac{\hat{y}_{2}^{2}}{\hat{\lambda}_{2}} \leq \chi_{2}^{2}(\alpha)=\frac{\hat{y}_{1}^{2}}{0.565431}+\frac{\hat{y}_{2}^{2}}{0.083180} \leq 5.99
$$

dimana $\chi_{2}^{2}(\alpha)=5.99$ dengan $\alpha=0.05$, diperoleh grafik elips sebagai berikut:

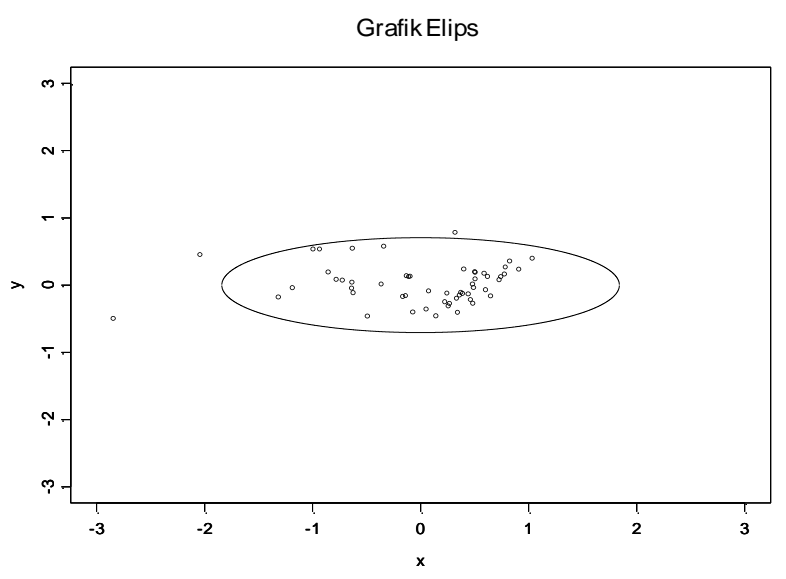

Gambar 1. Grafik Pengendali Elips

Pada Gambar 1, tampak ada 3 titik diluar elips. Hal ini mengindikasikan adanya ketidakstabilan dalam proses, penyebab khusus mungkin telah masuk ke dalam proses dan proses harus diperiksa untuk mengidentifikasi penyebab dari penyimpangan atau kesalahan tersebut. Ketiga titik tersebut adalah titik-titik pada observasi ke-12, 16 dan 55. 
Selanjutnya akan dilihat, bagaimana grafik pengendali yang menggunakan enam komponen utama terakhir sebagai variabelnya. Untuk itu digunakan grafik $T^{2}$, keenam komponen utama tersebut dihitung dengan menggunakan statistik:

$$
T_{j}^{2}=\frac{\hat{y}_{j 3}^{2}}{0.012355}+\frac{\hat{y}_{j 4}^{2}}{0.009288}+\frac{\hat{y}_{j 5}^{2}}{0.006801}+\frac{\hat{y}_{j 6}^{2}}{0.005900}+\frac{\hat{y}_{j 7}^{2}}{0.004220}+\frac{\hat{y}_{j 8}^{2}}{0.002667}
$$

dengan Batas Pengendali Bawah $(\mathrm{BPB})=0$ dan Batas Pengendali Atas $(\mathrm{BPA})=$ $\chi_{p-2}^{2}(\alpha)=\chi_{6}^{2}(0.05)=12.59$. Berdasarkan keterangan tersebut diperoleh grafik $T^{2}$ pada Gambar 2.

$\mathrm{T}^{2}$ Chart For National Track Record For Men

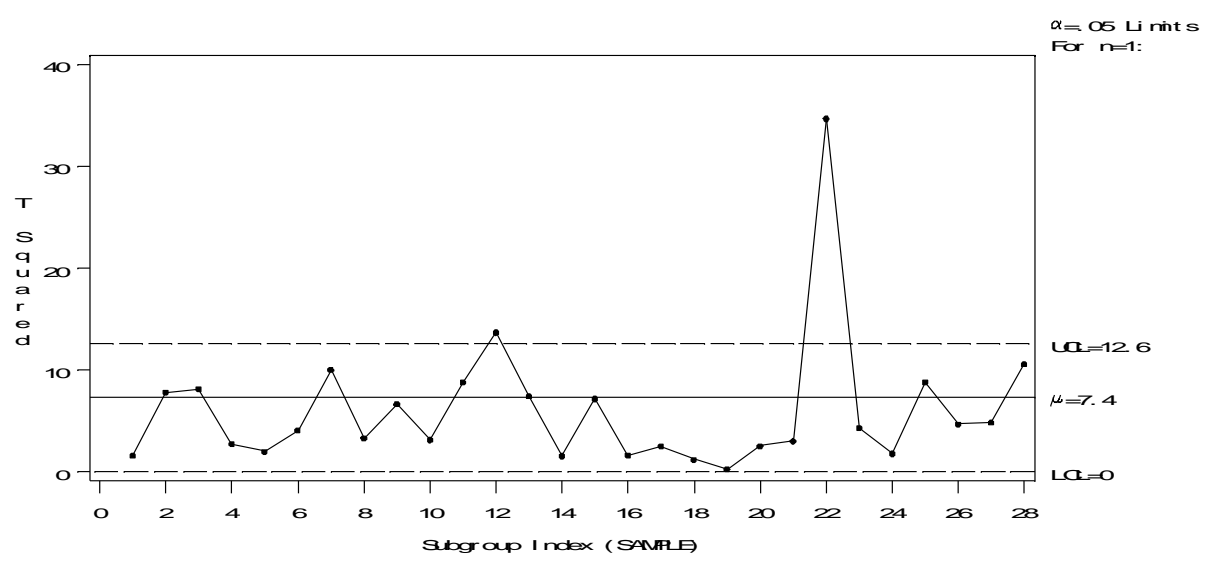

$T^{2}$ Chart For National Track Record For Men

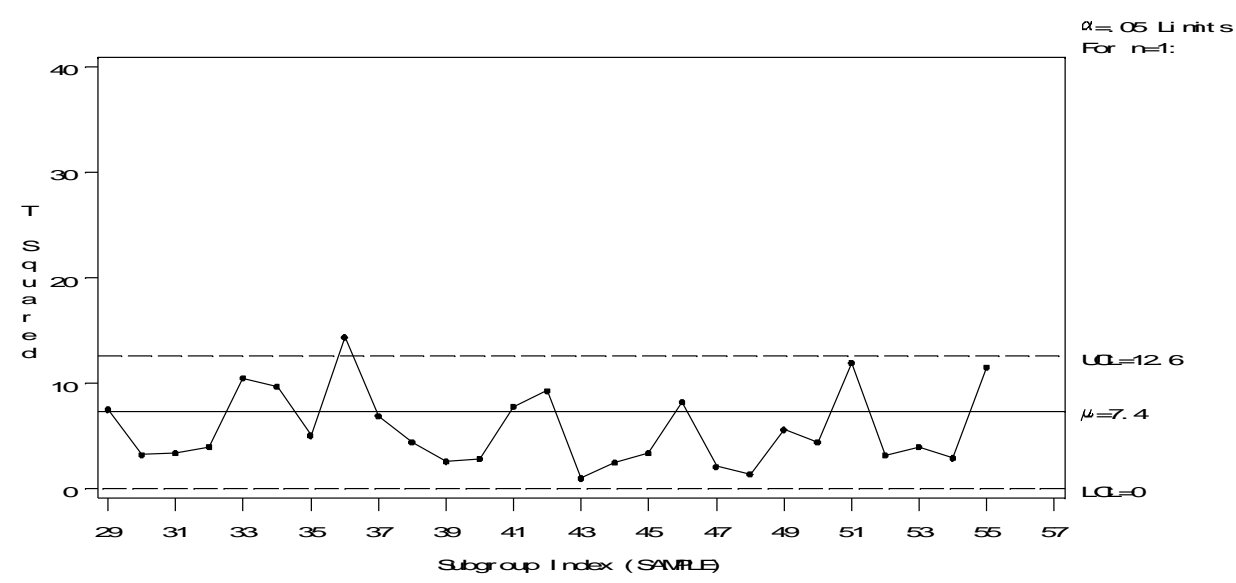

Gambar 2. Grafik $T^{2}$

Dari Gambar 2 diketahui ada 3 observasi yang berada di luar batas pengendali, yaitu observasi ke-12, 22 dan 36.

- $\hat{y}_{j 6}$ dominan pada observasi ke-12, dan koefisien yang dominan pada $\hat{e}_{6}$ adalah $x_{1}$ (catatan waktu atlet lari 100 meter) dan $x_{2}$ (catatan waktu atlet lari 200 meter). Dengan demikian Negara Cook Island perlu melakukan evaluasi atau tindakan perbaikan secara teknik pada atlet lari 100 meter dan 200 meter putra. 
- $\quad \hat{y}_{j 7}$ dominan pada observasi ke-22, dan koefisien yang dominan pada $\hat{e}_{7}$ adalah $x_{5}$ (catatan waktu atlet lari 1500 meter) dan $x_{6}$ (catatan waktu atlet lari 5000 meter). Dengan demikian Negara Greece (Yunani) perlu melakukan evaluasi atau tindakan perbaikan secara teknik pada atlet lari 1500 meter dan 5000 meter putra.

- $\hat{y}_{j 3}$ dominan pada observasi ke-36, dan koefisien yang dominan pada $\hat{e}_{3}$ adalah $x_{3}$ (catatan waktu atlet lari 400 meter) dan $x_{4}$ (catatan waktu atlet lari 800 meter). Dengan demikian Negara Mauritius perlu melakukan evaluasi atau tindakan perbaikan secara teknik pada atlet lari 400 meter dan 800 meter putra.

Setelah mengetahui adanya ketidakstabilan proses, maka dilakukan pengendalian kualitas secara statistik dengan membuang observasi yang berada di luar elips, yaitu observasi ke-12, 16 dan 55. Dengan demikian observasi berkurang menjadi 52 observasi. Hal ini berakibat didapatkannya komponen utama yang baru.

Dari dua komponen utama pertama diperoleh batas pengendali elips, yaitu:

$$
\frac{\hat{y}_{1}^{2}}{\hat{\lambda}_{1}}+\frac{\hat{y}_{2}^{2}}{\hat{\lambda}_{2}} \leq \chi_{2}^{2}(\alpha)=\frac{\hat{y}_{1}^{2}}{0.343007}+\frac{\hat{y}_{2}^{2}}{0.068602} \leq 5.99
$$

dimana $\chi_{2}^{2}(\alpha)=5.99$ dengan $\alpha=0.05$, diperoleh grafik pengendali elips sebagai berikut:

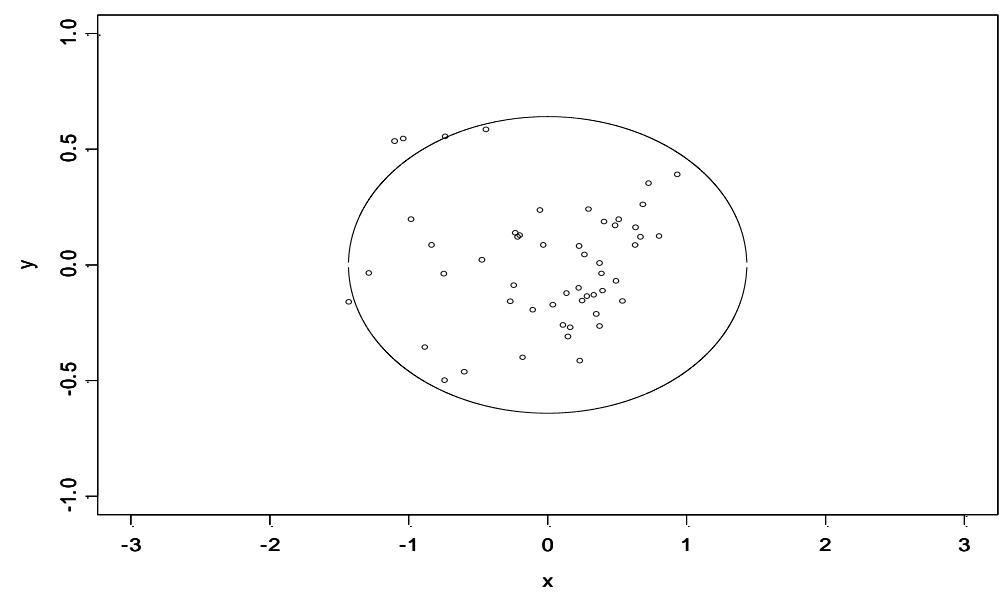

Gambar 3. Grafik Pengendali Elips

Pada Gambar 3 tampak ada 3 titik di luar elips. Hal ini mengindikasikan masih adanya ketidakstabilan dalam proses, penyebab khusus mungkin telah masuk ke dalam proses dan proses harus diperiksa untuk mengidentifikasi penyebab dari penyimpangan atau kesalahan tersebut. Selanjutnya akan dilihat, bagaimana grafik pengendali yang menggunakan enam komponen utama terakhir sebagai variabelnya. Untuk itu digunakan grafik $T^{2}$. Keenam komponen utama tersebut dihitung dengan menggunakan statistik:

$$
T_{j}^{2}=\frac{\hat{y}_{j 3}^{2}}{0.012338}+\frac{\hat{y}_{j 4}^{2}}{0.008459}+\frac{\hat{y}_{j 5}^{2}}{0.006324}+\frac{\hat{y}_{j 6}^{2}}{0.004531}+\frac{\hat{y}_{j 7}^{2}}{0.004204}+\frac{\hat{y}_{j 8}^{2}}{0.002592}
$$

dengan Batas Pengendali Bawah $(\mathrm{BPB})=0$ dan Batas Pengendali Atas $(\mathrm{BPA})=$ $\chi_{p-2}^{2}(\alpha)=\chi_{6}^{2}(0.05)=12.59$. Diperoleh grafik pengendali $T^{2}$ pada Gambar 4 .

Dari Gambar 4 diketahui ada 2 observasi yang berada di luar batas pengendali, yaitu observasi ke-20 dan 26. $\hat{y}_{j 7}$ dominan pada observasi ke-20, dan dari lampiran 5 pada 
Eigen Vektor koefisien yang dominan pada $\hat{e}_{7}$ adalah $x_{1}$ (catatan waktu atlet lari 100 meter). Dengan demikian Negara Greece perlu melakukan evaluasi atau tindakan perbaikan secara teknik pada atlet lari 100 meter putra. $\hat{y}_{j 5}$ dominan pada observasi ke-26, dan pada Eigen Vektor koefisien yang dominan pada $\hat{e}_{5}$ adalah $x_{4}$ (catatan waktu atlet lari 800 meter). Dengan demikian Negara Israel perlu melakukan evaluasi atau tindakan perbaikan secara teknik pada atlet lari 800 meter putra.

\section{$T^{2}$ Chart For National Track Record For Men}

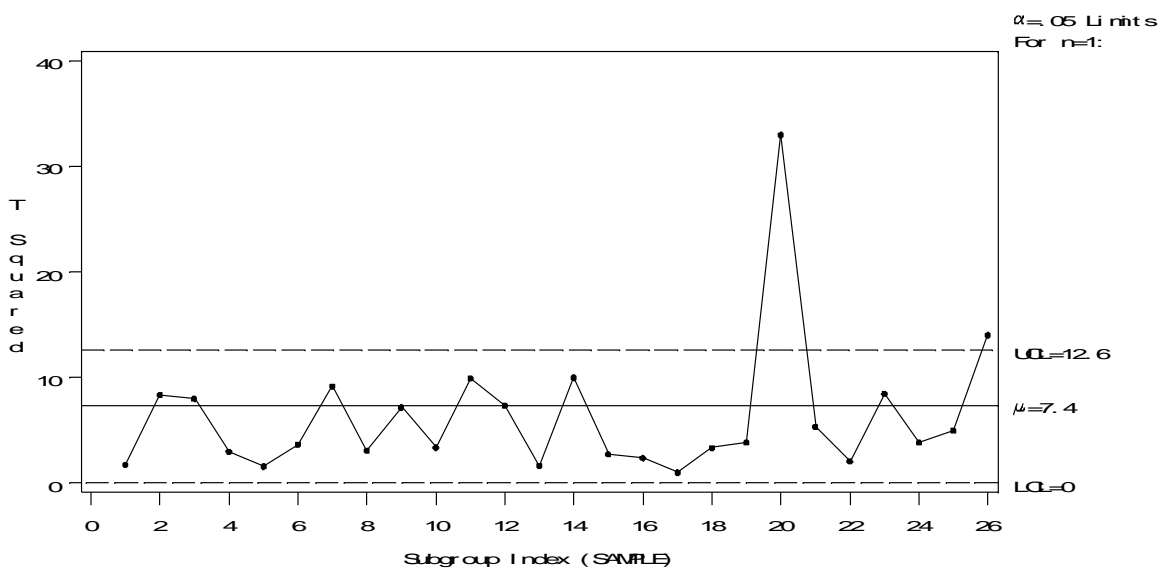

$T^{2}$ Chart For National Track Record For Men

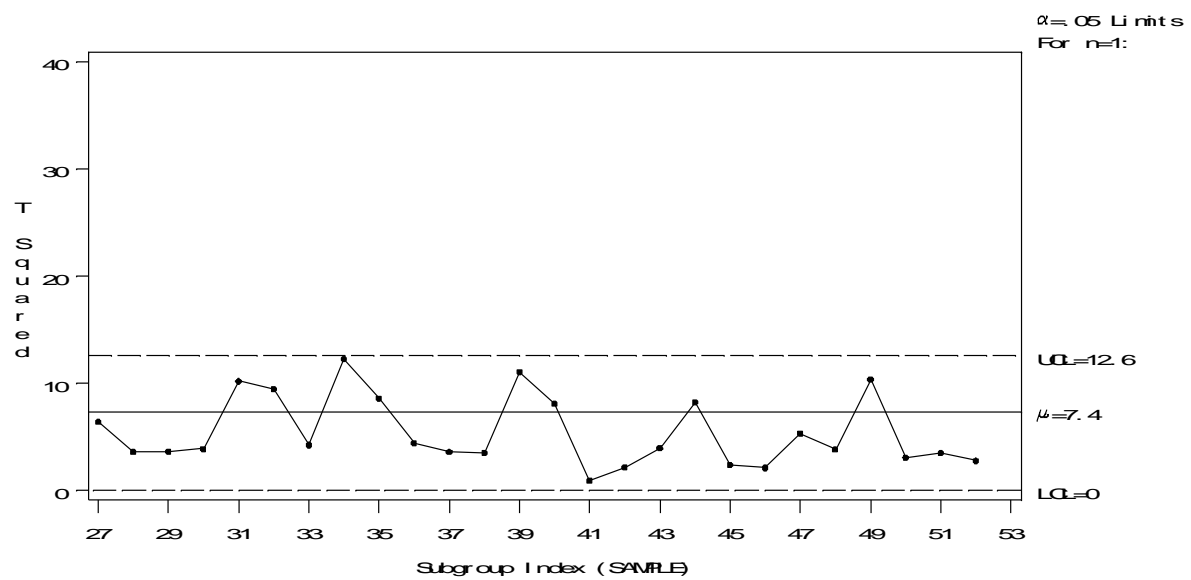

Gambar.4. Grafik $T^{2}$

\section{Kesimpulan}

Pengendalian kualitas secara statistik dengan menggunakan komponen utama dapat mendeteksi kesalahan atau penyimpangan secara statistik. Selanjutnya setelah dilakukan pengendalian kualitas secara statistik dapat dilakukan evaluasi atau tindakan perbaikan secara teknik sesuai dengan kasus yang dihadapi. 


\section{DAFTAR PUSTAKA}

1. Johnson, R.A. and Wichern, D.W., Applied Multivariate Statistical Analysis, Sixth Edition, Prentice-Hall International, Inc., New Jersey, 2002.

2. Montgomery, D.C., Introduction to Statistical Quality Control, Fifth Edition, John Wiley \& Sons, Inc., New York, 2005.

3. Sartono, B., dkk., Analisis Peubah Ganda, Departemen Statistika, Institut Pertanian Bogor, Bogor, 2003.

4. Sri Haryatmi, K., Metode Statistika Multivariat, Departemen Pendidikan dan Kebudayaan Universitas Terbuka, Jakarta, 1988. 